\title{
Management of Learning in Mawaddah Islamic Kindergarten and Sabilal Muhtadin Integrated Islamic Kindergarten
}

\author{
Ajizatur Rahmah ${ }^{1 *}$, Ahmad Suriansyah ${ }^{2}$, Erny Wahdini ${ }^{1}$ \\ ${ }^{1}$ Master Program of Early Childhood Teacher Education, Universitas Lambung Mangkurat, Banjarmasin \\ 70123, Indonesia \\ ${ }^{2}$ Master Program of Education Management, Universitas Lambung Mangkurat, Banjarmasin 70123, \\ Indonesia
}

Article history:

Submission November 2019

Revised April 2020

Accepted April 2020

*Corresponding author:

E-mail:

azizaturrahmah5@gmail.com

\begin{abstract}
The purpose of this research is to describe the planning, organization, implementation, and evaluation of learning in kindergarten students. It is a qualitative and multi-site study with data obtained from Mawaddah and Sabilal Muhtadin Integrated Islamic Kindergarten. Research results show that planning Weekly Learning Implementation Plan and Daily Learning Implementation Plan with an academic calendar organized following the Education Office, based on teacher expertise and distributing Standard Operating Procedures. Furthermore, students were grouped according to their habits, age, observation results, and the stage of development for one year. At the implementation stage, teachers were supervised, with learning taught according to the daily learning implementation plan, to meet children's needs and following the themes raised by the daily learning implementation plan. Evaluating the results of child development, with questions asked on the right learning material taught every month, with follow-up improvement to deal with children with special.
\end{abstract}

Keywords: Learning management, kindergarten

\section{Introduction}

Children are the next generation. On their shoulders, we surrender the civilization that we have built and we will leave (Mursid, 2016). Early childhood in the fastest development in various aspects there are religious, moral, social, intellectual, and emotion (Suyanto, 2005). Early childhood education aims to develop various aspects of children's potential (Zain et al., 2018). Learning in early childhood education that is playing while learning (Zahro, 2015).

Furthermore, it develops their social character, which reflects on their independent ability in primary school education (Safitri et al., 2018).

One of the efforts to increase the quality of education is improving the process of teaching and learning (Suryobroto, 2002). Focus on character development must be prioritized (Sukriani et al., 2017).

Salasiah et al. (2018) stated that the success in achieving educational goals is determined by the learning foundation and its elements such as students, educators, interaction, environment, learning materials. Learning becomes a complete cycle between assessment, planning, and implementation that goes on continuously (Yulaelawati, 2015). Partini (2010) evaluation guideline and the well-designed instruments.

According to Suriansyah et al., (2015), learning strategies are very important guideline components in the planning and implementation stages of kindergarten education to achieve set goals. In the philosophy curriculum, values and knowledge need to be 
integrated with educational action (Suhaimi \& Rinawati, 2018). Character building implemented from planning, implementation, and evaluation learning's steps in all subjects (Amri et al., 2011). Planning, organizing, implementation, and evaluation based on a learning document (Adzuardi, 2015). The teacher guides students to always learn, take initiatives, and express their ideas (Suriansyah, 2011). Learning of management through planning, organizing actuating, and evaluation (Al-Qorni, 2016). Planning in learning begins with arranging an annual, semester, weekly, and daily program (Hadiati et al., 2019).

Furthermore, every designed curriculum needs to reflect a school's vision, mission, and goals. The curriculum is also important to innovate, update and develop children for the future (Andriyani et al., 2018).

Metroyadi (2017) stated that active and fun learning tends to improve the quality of education outcomes. The learning environment has contributed to teacher's job satisfaction (Suriansyah \& Aslamiah, 2018).

All school members, including parents, carry out religious-based character education therefore, it becomes a real example for students (Cinantya et al., 2018). Parental involvement in the development of early childhood character is through building positive communication (Maimunah et al., 2018).

Therefore, organizations without adequate communication cannot develop optimally because it is the key to successful team effort (Suriansyah, 2014).

The strength of management greatly depends on the quality and role of the principal as a leader (Suriansyah and Aslamiah. 2015). Management of learning consists of planning, implementation, and evaluation of learning (Zubaidah, 2018). Learning in early childhood education through playing while learning (Agustin, 2011).

Based on the above descriptions, the objectives of this research are to describe the planning, organizing, implementing, and evaluating learning stages in Mawaddah Islamic and Sabilal Muhtadin Integrated Islamic Kindergarten in Banjarmasin.

\section{Methods}

This was qualitative research with a multisite study design in two kindergarten institutions. Its purpose was to identify and describe the elements and models of learning management implementation in Early Childhood Education.

\section{Results and Discussion}

The research results were obtained through interviews with teachers and the Head of Kindergarten. The results of interviews, observations, documentation, and research findings are as follows: In site 1 , interviews and documentation were conducted from 7 th to $21^{\text {st }}$ January 2019, at 02:00 PM, while observations were made from $22^{\text {nd }}$ to $30^{\text {th }}$ January 2019, at Mawaddah Kindergarten. In site 2, interview and documentation study were conducted from $11^{\text {th }}$ to 29 March 2019, at 02:00 PM, while observations were conducted from 15 $5^{\text {th }}$ February to $30^{\text {th }}$ March 2019 at 08:00 AM-01:00 PM at Integrated Islamic Kindergarten in Banjarmasin. The general description revealed based on the results of the study includes: (a) school identity, (b) research settings, (c) history, (d) school organizational structure, (e) vision, mission, and goals as well as (f) the situation of teachers, staff, and students.

The existence of Mawaddah Banjarmasin Islamic Kindergarten is recognized by the Ministry of National Education with identity number provided for the school as follows: (1) Learning planning: This consists of making semester programs, with weekly/daily learning implementation plan (weekly and daily), which are determined through meetings with the Kindergarten Head, teachers, and administrative staff. (2) Organization: Making a school independent education calendar in determining effective and ineffective days, as well as ways to make teaching assignments or group children. (3) Implementation: This determines the various ways to monitor the teaching process following how the teacher opens and closes learning. (4) Evaluation: This determines the best ways to evaluate results of child development, teacher learning, strategies, 
and follow-up steps to improve learning activities to ensure proper children's development, with the right strategies and follow-up steps.

These agree with Suharni (2019) where is program management was prepared following the vision and mission of the institution by implementing management functions including planning, implementation, supervision, and guidance. Based on the data that has been described, it was found that both schools carried out planning on learning. They assumed that in making learning plans, it is important to start with the Semester Program, weekly, and daily activity. (Rozalena, 2017) stated that the learning planning strategy should pay attention to SKH (Daily Activities Unit) and SKM (Weekly Activities Unit).

Setiyadi (2013) stated that planning in PAUD Firdausy Sukoharjo is following the Learning Menu Reference in playgroups. This is the same as the results of research conducted by Putri (2008), which showed that (1) the management of learning centers and circles in the Anak Saleh and Taman Harapan Study Groups, included the stages of planning, organizing, implementing, and evaluating. Their learning planning was carried out daily, weekly, monthly, or annually by a team consisting of the principal, family planning coordinator, class, and center teachers. In the Anak Saleh Study Group, learning activities were carried out in the following order: morning exercises, eating together, transition, environmental, footing before, during, and after playing, and closing activities. While in Taman Harapan Learning Group, learning activities were carried out in sequence, as follows environmental footing, morning exercises, transition, footing before, during, and after playing and closing activities. Assessments were carried out in the Anak Saleh and Taman Harapan study groups, in daily, weekly, midterm, and semester. Nugraha (2016) stated that planning that can be done is understanding the curriculum, look at the child's developmental needs, consider the environment, and make long and, short term learning programs. (Afifah et al., 2019) learning is designed by making curriculum guidelines, academic calendars, determining themes, learning schedules, and daily activity.
The organization is implemented by making organizational structure and daily task distribution. Rahayu (2015), in the thesis entitled "Management of Learning in the Context of Developing Student Intelligence in Kusuma Mulia Kindergarten in Ngadiluwih, Kediri Regency," stated that learning management in the context of developing multiple intelligences of students in Kusuma Mulia Kindergarten was carried out through planning, implementation, evaluation, as well as supporting, and inhibiting factors. The planning stage of learning management in the context of developing students' multiple intelligences includes three activities, such as (1) Making a routine and regular daily activity plans, which is followed by weekly, annual, and semester program based on the curriculum. Thirdly, class planning is adjusted to the needs and activities of developing multiple intelligences of students. (2) The implementation activities include initial, core, and final activities, with the use of two forms, variations, assignments, environments conditioned to support the development of students 'multiple intelligences, and preventive actions to keep the situation conducive in the second, third, fourth, fifth, sixth and seventh classes. (3) The evaluation phase consists of a daily and semester evaluation, as seen from the work completion process and work results, behavior, of 4-5 children. (4) Supporting factors in learning management in the context of developing students' multiple intelligences in Kusuma Mulia Kindergarten in Ngadiluwih, Kediri, which include creative and innovative teachers that support curriculum development, by providing sufficient supporting facilities, in dynamic classes. (5) The inhibiting factors include insufficient number $\mathrm{f}$ classrooms and a small playing field. (Putri et al., 2017) there was a significant difference in early childhood problem-solving skill before and after scientific approach based on learning been applied. Farida (2017) (1) learning syllabus is written in the form of a planning semester, weekly planning, and a daily planning/meeting. Planning is done by paying attention to the level of development, needs, interests, and characteristics of students, and aspects of development include 
religious and moral values, motor, cognitive, language, and social-emotional. (2) The implementation of learning in Kindergarten A Nurur Ra'uf starts with (a) happy morning, (b) habituation activities, (c) transitions, (d) environmental footing, (e) footing before playing, (f) footing during play, (g) footing after playing, (h) introduction of prayer, and (i) closing. Implementation of learning using the method of playing while learning through learning center class with the Beyond Center and Circle Time (BCCT) approach, and the question method answer, story, play a role or practice directly in the field. Activities carried out in an atmosphere play comfortable, safe, clean, and healthy. (3) Learning assessment in Kindergarten A Nurur Ra'uf carried out by observation at any time, not during the KBM lasted until finished learning. through observation, anecdotal recording, and portfolio. According to Al-Qorni, (2016), the learning process includes the following 1.) Planning, the learning process in Khalifah Kindergarten which comprises of Daily, weekly and annual activities plan, 2.) Organizing by first preparing the facilities and equipment for teaching and learning activities, such as syllabus in the form of materials, for students and teachers to conduct teaching and learning activities. 3.) Implementing the learning through the initial, core, midday prayer, and closing activities. The factors that support learning management include teachers, students, curriculum, facilities and infrastructure, parents/guardians, and the community. Inhibiting factors include the limitations of teachers in educating children, high school fees, and less active socialization. Furthermore, the evaluation process was carried out by measuring the ability of children in the task by analyzing their assessment sheets. The form of assessment uses qualitative evaluation, which is stated by the phrases "rarely," "often," and "sometimes." The aspect of evaluating learning is the same as the results of research conducted by Adzuardi (2015) entitled "Learning Management of Early Childhood Education." The results showed that: (1) learning planning is based on the education unit level not using the 2013 curriculum. (2) The implementation of the learning program is developed by tutors. (3) Technically, supervision and evaluation of learning are carried out by formal education supervisors at the kindergarten level and also by observers (Lestari, 2018). The results of the study described that: (1) the initial step of learning planning prepared a semester activity plan, which spelled out to the weekly activity plan arranged in the form of opening, core, and closing activities. After that, the infrastructure needed for teaching is prepared. (2) organizing was carried out by the division of teachers by the school principal with language lessons, Islamic Religious Education (PAIS), and SocialEmotional allocated. (3) Learning implementation using storytelling in character development was delivered in the form of fairy tales, stories of the Prophets and Apostles, and spontaneous daily events. It was carried out for children to visualize and remember the incident. (4) The evaluation was in the form of performance, observation, structured and unstructured conversation, and the contact book. (Rosiana et al., 2009) learning planning must be following the curriculum used. According to Ita (2018), the planning of learning is made in the form of syllabus, the semester planning, weekly activities planning, daily activities planning. In making the learning planning the kindergarten teachers need to consider the level of childhood development, the children development aspects, the children's needs, the children's interest, and the children's characteristics, 2) the implementation of learning in Rutosoro kindergarten begins with the welcoming of the children by the teachers, introduction (moving together, praying, presenting, questioning on themes and subthemes), core activities, eating and resting, closing. Implementation of learning using the methods adapted to the theme with the principle of playing while learning, and 3) the assessment of learning is done every time since the children come to the school till the children go back to home through the assignment, conversation, observation, performance, work, and portfolio. According to Zubaidah (2018), the results of the study showed that: (1) the learning plan of Idhata, Miftahul Ulum Islamic, and al-Madani Integrated Islamic Kindergarten were carried out before the new school year. Those of Idhata 
and Miftahul Ulum were less organized in contrast to Al-Madani Integrated Islamic Kindergarten. (2) Organizing the curriculum at Idhata Kindergarten includes extra activities and habituation. While at Miftahul Ulum Islamic Kindergarten and Al Madani, it consisted of a core, religious, and extra activities. extra activities and habituation. (3) The learning implementation in both schools used a group of the model, while in al-Madani Integrated Islamic used the center learning model. In Idhata and Miftahul Ulum the core activities and religious curriculum were implemented with the group learning model, and in al-Madani, the habituation model was implemented. (4) The learning assessment in Idhata, Miftahul Ulum, and al-Madani Integrated Islamic Kindergarten was carried out from the start of daily activities. Assessment tools at Idhata Kindergarten include observation, anecdotes, activities, and assignments, while in Miftahul Ulum Islamic Kindergarten includes the scale of development achievements, anecdotes, and students' work. At Al-Madani Integrated Islamic Kindergarten includes observations, anecdotes, and the students' work.

\section{Conclusion and Recommendation}

Planning of learning was carried by planning semester, weekly and daily programs which include students' assessment books, anecdotal records, stages of play, and habituation activities.

Organizing of learning begins with the creation of a school independent education calendar referenced to the Education Office. Then modified according to school activities, and observations at the beginning of kindergarten based on evaluation of their developmental stage for one year.

The implementation of learning by the head began with supervision, according to the daily plan, with assessment properly carried out to determine the ability of teachers and their respective expertise. Implementation needs to meet the children's needs, such as toilet training, morning journal, material activities, motivation following the theme, implement work procedures, pray, and providing relevant information.
Evaluating of learning conducted by the Head of the kindergarten, starts from evaluating the results of children's development with questions and answers on the material taught from the stage of development for one year, through Daily, weekly, monthly, semester and yearly assessments. It was carried out by observation, anecdotal records, portfolios, work, and demonstrations. Teachers' evaluation of the learning procedure is carried out once a month, and the results are followed-up to improve learning with supervision results submitted for evaluation.

To create an innovative, creative, and comprehensive effort to improve services for students, kindergarten managers need to motivate educators and staff in equating perceptions and understanding their tasks and functions. Furthermore, planning needs to be arranged in accordance with the vision and mission of the institution to improve the surrounding community. Managers, educators, and administrative staff need always to improve communication and coordination in kindergarten schools.

\section{Acknowledgment}

The authors thanks to Universitas Lambung Mangkurat Banjarmasin for supporting this research.

\section{References}

Adzuardi. (2015). Learning of management in early childhood education. Palembang: South Sumatra Culture and Tourism Agency.

Afifah, N., Suriansyah, A., \& Aslamiah. (2019). Implementation of Islamic aqeedah based curriculum. Journal of K6, Education and Management,2(1), 47-57.

Agustin, U. W. (2011). Penilaian perkembangan anak usia dini. Bandung: PT. Refika Aditama.

Al-Qorni, W. (2016). Learning of management in invest the unity of the god values and enterpreneurship in khalifah kindergarten of Yogyakarta. Yogyakarta: Pascasarjana Universitas Islam Sunan Kalijaga.

Amri, S., Jauhari, A., \& Elisah, T. (2011). Implementasi pendidikan karakter dalam pembelajaran. Jakarta: PT. Prestasi Pustakarya. 
Andriyani, E., Ngadimun, \& Suriansyah, A. (2018). Character education management. IOSR Journal of Research \& Method in Education (IOSR-JRME), 8 (6), 13.

Cinantya, C., Suriansyah, A., \& Asniwati. (2018). The model of religion-based character education (multi-site integrated islamic PAUD sabilal muhtadin and PAUD islam mawaddah Banjarmasin, Indonesia). European Journal of Education Studies, 5 (7), 10.

Farida, S. (2017). Pengelolaan pembelajaran PAUD. Jurnal Pemikiran, Penelitian Pendidikan, dan Sains, 5 (2), 189-200.

Hadiati, Eti \& Fidrayani. (2019). Manajemen pembelajaran pada anak usia dini. Jurnal Ilmiah Pendidikan Anak Usia Dini, 2 (1), 69-78.

Lestari, R. M. (2018). Management of learning in early childhood education with telling story method in develop the character (case study in Al-Hidayah Sondriyan Kendal Ngawi Raudathul Atfal). Ponorogo: Program Studi Manajemen Pendidikan Islam IAIN Ponorogo.

Maimunah, M., Aslamiah, A., \& Suriansyah, A. (2018). The integration of sentra-based learning and involement of family program at early childhood in developing character building (multi case at PAUD Mawaddah and PAUD Alam berbasis karakter sayang ibu Banjarmasin, Indonesia. European Journal of Education Studies, 5(7), 49-63.

Metroyadi. (2017). The effort to develop an aspects of religious and moral values in distinguish a good and bad action used example and non example model with audio visual media variations on children of group B in Aisyiyah Bustanul Athfal 31 kindergarten Banjarmasin. Sagacious Scientific Journal of Education and Social, 4 (1), 10-11.

Mursid. (2016). Learning of the developmet early childhood education. Bandung: PT. Remaja Rosda Karya.

Nugraha, Bayu. (2016). Manajemen pembelajaran gerak untuk anak. Jurnal Olahraga Prestasi, 12 (1), 111-117.

Partini. (2010). The introduction of the early childhood education. Yogyakarta: Grafindo Litera Media.

Putri, A. P. (2008). Learning of centers and circles management (multi-case study early childhood education instituation Anak Saleh playgroup and Taman Harapan playgroup in Malang). Malang: Faculty of Education, Universitas Negeri Malang.

Putri, C. E., Haenilah, E. Y., \& Surahman, M. (2017). Pembelajaran ilmiah bagi anak usia dini. Jurnal Pendidikan Anak, 3(2), 18.

Rahayu, E. F. (2015). Learning of management in order to development the multiple intelligences's child in Kusuma Mulia Ngadiluwih kindergarten Kediri District. Kediri.

Rosiana, Zulita, \& Bambang. (2009). Manajemen pembelajaran PAUD (studi deskriptif kualitatif pada kelompok bermain di PAUD SREDTTA kota Bengkulu). Bengkulu: Fakultas Keguruan dan Ilmu Pendidikan UNIB.
Rozalena. (2017). Pengelolaaan pembelajaran PAUD dalam mengembangkan potensi nak usia dini. Jurnal Manajemen, Kepempimpinan, dan Supervisi Pendidikan, 2 (1), 67-86.

Safitri, M. E., Ahmad, K. I., \& Saleh, M. (2018). Development of child independence through model picture and picture, examples non examples model and practical method directly activities of learning practical ife in group B Kasih Ibu kindergarten. European Journal of Education Studies, 5 (7), 6480

Salasiah, Asniwati, \& Effendi, R. (2018). Instilling character values in early childhood in the perspective of curriculum and parenting (multi-site study in PAUD Islam Sabilal Muhtadin and PAUD Mawaddah, Banjarmasin, Indonesia). European Journal of Education Studies, 5 (7), 41.

Setiyadi. (2013). Pengelolaan pembelajaran pada PAUD Firdausy Sukoharjo. Surakarta: Program Pascasarjana Magister Manajemen Pendidikan Universitas Muhammadiyah.

Suhaimi, \& Rinawati, Y. (2018). Management of character curriculum education at vocational high school 2 Kandangan. Advances in Social Science, Education and Humanities Research, 274, 273.

Suharni. (2019). Manajemen pendidikan anak usia dini pada PAUD Bintang Rabbani Pekanbaru. Jurnal Ilmiah Potensia $4(1), 1-5$.

Sukriani, Huda A.Y, M., Arifin, I., \& Suriansyah, A. (2017). The Implementation of The Islamic Schools Resources Total Quality Management in Banjarmasin, Indonesia. Journal of Social Sciences (COES\&RJ-JSS), 6 (1), 135.

Suriansyah, A. (2011). Character education in national perspective education system. Education Science, 6 (11), 117-130.

Suriansyah, A. (2014). The relationship between school culture, communication, and work commitment to the teacher's performance in public elementary school. Education Cakrawala, 3, 359.

Suriansyah, A. (2015). The headmaster, teacher, parents, and public strategy to form the student's character. Education Cakrawala, XXXIV (2), 242.

Suriansyah, A., \& Aslamiah. (2015). The leadersip strategies of school, principals, teachers, parents, and the communities in building the Students character. Banjarmasin: Education Cakrawala, XXXIV (2), 1-9.

Suriansyah, A., \& Aslamiah. (2018). Teacher's job satisfaction on teacher's job satisfaction on elementary school: relation to learning environmentact. The Open Psychology, 11, 123130.

Suryosubroto. (2002). The process of teaching and learning in the school. Jakarta: Rineka Cipta.

Suyanto, S. (2005). Pembelajaran untuk anak TK. Jakarta: Departemen Pendidikan Nasional Direktorat Pembinaan Pendidikan Tenaga Kependidikan dan Ketenagaan Perguruan Tinggi. 
Yulaelawati, E. (2015). Penyusunan rencana pelaksanaan pembelajaran pendidikan anak usia dini. Jakarta: Direktorat Pembinaan PAUD.

Zahro, I. F. (2015). Penilaian dalam pembelajaran anak usia dini. Bandung: PG PAUD Stikip Siliwangi.

Zain, A., Saleh, M., \& Noorhapizah. (2018). Strategy for the development of religious workship and religious tolerance at Widya Dharma early childhood education in Banjarmasin
City, Indonesia. European Journal of Education Studies, 5 (7), 89.

Zubaidah. (2018). Management of learning in early childhood education at Tapin Distict (multi case study at Idatha kindergarten, Miftahul Ulum raudathul atfal, and Al-Madani integrated islamic kindergarten). Banjarmasin: Universitas Islam Negeri Antasari Banjarmasin. 